\title{
XIV. An account of the sugar maple of the United States, communicated by Robert John Thornton, M. D. Lecturer on Medical Botany at Guy's Hospital
}

\section{Benjamin Rush M.D. \& Robert John Thornton M.D.}

To cite this article: Benjamin Rush M.D. \& Robert John Thornton M.D. (1798) XIV. An account of the sugar maple of the United States, communicated by Robert John Thornton, M. D. Lecturer on Medical Botany at Guy's Hospital , Philosophical Magazine Series 1, 1:2, 182-191, DOI: 10.1080/14786447808676819

To link to this article: http://dx.doi.org/10.1080/14786447808676819

Published online: 04 Mar 2010.

Submit your article to this journal ๔

Џ Article views: 2

View related articles $\sqsubset$ 
fome frem leaves, minced as has been directed, may be in. fufed in a mixture of vitriolic acid and water, of about tha degree of acidity of vinegar; and it may be neutralifed as it is wanted, by chalk, or fixed or volatile alkali. Avoid an excefs of alkali, as it will turn the colour yellow.

By the fame procefs Mr. Watt made a red infuion of violets, which on being neutralifed formed a very fenfible teft; but how long it might be preferved, he had not determined.

Mr. Watt recommends to ufe the tefts in a liquid ftate; as he obferves, and with juftice, that the fize and alum in writing-paper in fome degree fix the colour, while paper not fized becomes too tranfparent, when wetted, to render fmall changes of colour perceptible.

To the above ufeful hints of Mr. Watt we fhall add another.-The fkins of red radihes yield by being bruifed a very fenfible tert, and, no doubt, might be preferved by the means he has pointed out.

XIV. An Account of the Sugar Maple of tbe United States, by Benuamin Rush, M.D. Profiffor of the Infiztutes of Medicine in the Univerjity of Pennjylsania, communicated by Robert John Thornton, M.D. Leifurer on Medical Botany at Guy's Ho/pital.

$\mathrm{T}$ HE acer faccharimum of Linnæus, or figar maple tree, is found in great abundance in the weftern counties of all the middle ftates of the American Union. Thofe which grow in New York and Penafylvania yield the fugar in a greater quantity than thofe which grow on the water of the Ohio. They are when at maturity, that is, when about twenty years old, as tall as an oak, and from two to three feet in diameter. They put forih a beautiful white blofom in the fpring before they thew a fingle leaf. The colour of the bloffom difinguilhes the figar maple from the acer rubrum, or conmon manle, which has a red fowcr. Its fnall 
branches were cut by the firf fetters for the fupport of cattle during the winter, who throve greatly upon them. The wood is extremely inflammable, and therefore makes fine fire-wood. Its athes afford a great quantity of pot-alh, cxcected by fer, or perhaps by none, of the trees that grow in the woods of the United States.

The acer faccharinum is not injured by tapping; on the ecntrary, the oftener it is tapped, the more fyrup is obtained from it. The effects of a yearly difcharge of fap from the tree in improwing and increafing the fap, is demonftrated from the fuperior excellence of thofe trees which have been perforated in an hundred places by a fmall wood-pecker which feeds upon the fap. The fap of fuch trees is much fwecter to the tafte than that obtained from trees which have not been previoufly wounded, and more fugar is afterwards procured. In this latt particular it follows a law of the animal reconomy. It is well known, that when at perfon has been once tapped, the procefs requires afterwards to be more frequently repeated. A fingle tree bas not only furvised, but flowined after forty-two tappings in the fame number of years.

A tree of an ordinary fize yidds, in a grod feafon, from iwenty to thirty gallons of fap, from which are made from five $10 \mathrm{fx}$ pounds of fugar. To this there are fonetimes remarkable exceptions. Smmol Low, bro. a jullice of peace in Montgomery county, in the State of New York, inforned Arthur Noble, Fiq. that he had made twoty pounds and one ounce of fugar from the Ifth to the 2 gh of April, in the year 1789 , from a fingle tree that had been tapped for feveral fucceffive years before. The quantity obtained per dien varics from five gallons to a pint, according to the variations of the weather. 'The infuence which this has in increang: or leffoning the difcharge of the fap is vory ronarkable. I have feen a journal of the effects of heat, cold, mifure, drought, and thunder, upon the difcharges from the fugar trec; which difpofes me to believe there is fome foundation 
in Dr. Tongue's opinion, who fuppofes that changes in the weather of every kind might be as readily afcertained by difcharges of fap from trees, as by the barometer. (Vide Philofophical Tranfactions, $N^{\circ}$ 68.) Warm dạys fucceeding frofty nights are moft favourable to a plentiful difcharge of fap. If frofty nights fucceed a warm day, there is always a total fufpenfion of the difcharge $*$.

The

* Dr. Hale, in his Vegetable Statics, relates that he cut down a vine, and cemented to its mutilated ftump glafs tubes, each 7 fcet long, and one fourth of an inch diameter, with brafs caps, by which they were focewed on one above another, till they rofe to the height of 36 fcet.

By thefe gages it appeared,

xft. That the fap began to rife March 10, when the thermometer by day frood only at 3 degrees above the frcezing point.

2dly. Thar, April $\mathrm{I} 8$, it was at its height and rigour.

$3 \mathrm{dly}$. That from that time to May 5, the force gradually decreafed.

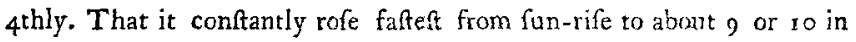
the morning, and then gradually fubfided till about 5 or 6 o'clock in the afternoon.

$5^{\text {thly. That it rofe fooner in the morning after ccol weather, than after }}$ hot days, and in proportion to the coldects of the night and fubfequent heat.

6thly. That after feveral fucceffive cold days and nights, the fap would rife during the whole day, if it chanced to be fine, although floweft at noon.

7thly. That if warm weather had made the fap flow rigoroufly, that vigour would be abated immediately by a cold eafterly wind and a cloudy fun, when the fap would fink at the rate of an inch per minute; but when the fun thone out, and the wind thifted, it rofe again as ufual.

8thly. The oldeft vines were fooneft affected by a change of tcmperature, and in them the fop irft began to fink.

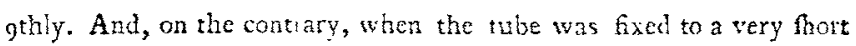
ftump of a young vine, and at only 7 inches from the ground, the fap flowed incefantly, and fatteit cf all, in the gyeateft heat of the day, fuking only after fun-fet.

He then makes this general concluron, that the rapinity with which the fap circulates in the vine duing the fpring, is five times greater than the rapidity with which the blow fluws in the arteries of a horie; that it is confiderably lower in the fummer than in fpring, very languid in autumn, and ccares altogether in the winter. 
The fap ufually flows for fix weeks, varying according to the temperature of the weather. The feafon for tapping is in February, March, and April. During the remaining part of the fpring months, as alfo in the fummer, and in the beginning of autumn, the maple tree yiclds a thin fap, but not fit for the manufactory of fugar.

Baron La Hontan gives the following account of the fap of the fugar maple tree, when ufed as drink, and the manner of obtaining it. The tree, fays he, yields a fap which has a much pleafanter tafte than the beft lemonade or cherry water, and is the wholefomelt drink in the world. This liquor is drawn by cutting the tree two inches deep in the wood, the cut being made floping to the length of ten or twelve inches; at the lower end of this gafh, a knife is thruft into the tree flopingly, fo that the water runs along: the cut or gafl, as through a gutter, pervades the knife, and falls upon fome veffels placed underneath to receive it. The gafh does no harm to the tree. Some trees will yield five or fix bottles of this water in a day, and many inhabitants of Canada might draw twenty hogtheads of it in one day, if they had a mind to notch all the maple trees upon their plantations; but common things are flighted, and fcarce any but children think of extracting this liquor from the trees.

The mode of tapping is different, and is performed with an axe or an auger. The latter is preferred, from experience of its advantage. It is introduced about three quarters of an inch, and is afterwards deepened gradually to the extent of two inches. A fpout is introduced about half

The above experiments clearly demonftrate, that it is not from heat and light alone that the fap rifes in the vine, or any other tree; for, if that were the cafe, it would increafe as the heat increafed; it would be greateft in the noon-day, and in the height of fummer, and lefs in fpring than in autumn, whercas the reverfe is here fhewn to be the cafe. It muft therefore dcpend on the irritability of the fiores compofing the reffels, which gets exhaufted by the fimulus of heat and light, and is accumulated by its ablence. $T$, 
an inch into the hole, and it projects from three to twelve inches. The operation of tapping is firft done on the fouth fide; and when the difcharge of fap lefiens, an opening is made with the auger on the north fide, when an abundant How takes place.

Wooden troughs large enough to contain three or four gallons are placed under the fpout to receive the fap, which is carried every day to a large receiver made of wood. From this receiver it is conveyed, aftcr being ftrained, to the boiler. The following facts have been afcertained by experiment: The fooner the fap is boiled, after it is collected from the tree, the better. The larger the vefel the more fugar is obtained. The fugar is allo improved by ftraining the fap through blankets, or cloth, either before or after it is half boiled. Some fatty fubftance is added to the fap in the kettle, to prevent its boiling over. Lime, eggs, or new milk, is mixed with it in order to clarify it. I have fcen clear fugar made without the addition of either of them. A fpoonful of llack lime, the white of one egg, and a pint of new milk, are the ufual proportions of thefe articles, which are nixed with fifteen gallons of fap. The maple-fugar clarified with milk alone had the evident fuperiority of all others. After being fufficiently boiled, it is grained, and clayed, and afterwards rifined, or converted into loaf fugar. The method of conducting each of thefe proceffes is fo nearly the fame with thofe which are ufed in the manufactory of Weft India fugar, and are fo generally known, this I need fpend no time in defcribing them.

There are two other methods of reducing the fap to fugar. The firt is by fieezing. This method was tried by Mr. Scolt, a farmer in this ftate, with great fuccefs. He fays, that one half of a given quantity of fup reduced in this way, is bette: than one third of the fame quantity reduced by boiling. $1 f^{\circ}$ the froft fhould not be intenfe enough to reduce the fup to the graining point, it may afterwards be expofed to tho action of fire for that purpofe. 


$$
\text { Airount of the Aneritan Sugar Maple. }
$$

Secondly, by jpontancous a aporation. The hollow fump of a niaple fugar tree, which had been cut down in the fprines, and which was found fome time after filled with fugar, firt fuggefted to our farmers this method of obtaining fugar. So many circumftances of cold and dry weathcr, large and fiat reffels, and above all fo much time is neceffary to obtain fugar by either of the above methods, that the moft general method among our farmers is to obtain it by boiling.

The kettles and other utenfils of a farmer's kitchen will lerve moft of the purpofes of making fugar, and the time required for the labour (if it deferves that name) is at a fealon when it is impoffible for the farmer to employ himfelf in any fpccies of agriculture. His wife, and all his children above ten years of age, may affift him. The following receipt was publihed in the Albany Gazette: "Received of William Cooper, Efq. fixteen pounds for 640 pounds of fugar, made with my own hands, without any affiftance, in lefs than four weeks, befides attending to all the other bufiness of the farm. John Nicholls." - A fingle family confifing of a man and his two fons, on the Maple Sugar Lands between the Delaware and Sufquchannah, made I 800 pounds of maple fugar in one feafon. Not more knowledge is neceffary for making this fugar, than is required to make cyder, beer, \&c. and yet one or all of them are made in moft of the farm-houfes in the United States.

Let us now take a comparative view of this fugar with that cbtained from the cane, with refpect to its quality, price, and the quantisy that might probably be made in the United States, each of which I fhall confider in order:

I. The quality of this fugar is neceffarily better than that which is made in the Weft Indies. It is prepared in a feafon when not a fingle infect exifts to feed upon it, or to mix its excretions with it. The fame obfervation cannot be applied to the Weft India fugar. The infects and worms which prey upon it, and of courfe mix with it, compofe a page in a nomenclature of matural hiftory. I thall fay no- 
thing of the hands which are employed in making fugar in the Weft Indies; for llaves have not that obligation to cleanlinefs which thofe have who work for their own benefit, and have received a proper education. It has been conceivcd that the maple fugar is inferior to the Weft India fugar in ftrength. The experiments which led to this opinion I fufpect have been inaccurate, or have bcen made with maple fugar prepared in a flovenly way. I have examined equal quantities by weight of both the grained and the loaf fugar, in hyfon tea, and in coffee, made in every refpect equal by the minuteft circumftances that could affect the quality or tafte of each of them, and could perceive no inferiority in the ftrength of the maple fugar. The liquors which were to decide this queftion were examined at the fame time by Alexander Hamilton, Efq. fecretary of the treafury of the United States, Mr. Henry Drinhur, and feveral ladies, who all concurred in the above opinion.

2. Price. Whoever confiders that the gift of the fugar maple tree is from a benevolent Providence; that we have many millions of acres in our country covered with them; that the tree is improved by repeated tappings; and that the fugar is obtained by the frugal labour of a farmer's family; and at the fame time confiders the labour of cultivating the fugar cane, the capitals funk in fugar works, the firt coft of flaves and cattle, and the expences of provifions for both, \&c. will not hefitate in believing that the maple fugar may be manufactured much cheaper, and fold at a confiderably los; price than that which is made in the Weft Indies.

3. The refources for making a fufficient quantity of this fugar, not only for the confumption of the United States, but for exportation, will appear from the following facts:-There are in the ftates of New York and Pennfylvania alone, at leatt ten millions of acres of land which produce the fugar maple tree in the proportion of thirty trees to one acre. Now, fuppofing all the perfons capable of labour in a family to confift of three, and each perion to attend $\mathrm{r} 50$ trees, ank 
tach tree to yield 5 pounds of fugar, the product of labour of 60,000 families would be $135,000,000$ pounds of fugar, and, allowing the inhabitants of the United States to compofe 600,000 families, each of which confumed 200 pounds of fugar a year, the whole confumption would be $120,000,000$ pounds a ycar, which would leave a balance of $15,000,000$ pounds for exportation. Valuing the fugar at $6-90$ of a iollar per pound, the fum faved would be $8,000,000$ dollars of home confumption, and the fum gained by exportation would be $1,000,000$ dollars.

The maple fugar alfo affords excellent vinegar; its molafez is capable of affording a very pleafant fumnier beer. The fap is alfo capable of producing fpirit; but we hope this wholefnme juice will never be proftituted to fuch a purpofe. A diet confifting of a plentiful admixture of lugar has many advantages.

Sugar affords the greateft quantity of nourifhment in a given quantity of matier of any fubftance in nature. Hence the Indians ufe it in their excurfons. They mix a certain quantity of maple fugar with an equal quantity of Indian rorn, dricd and powdered. This mixture is packed up in litile bafkets. A few fpoonfuls of it nixed with half a pint if fpring water, afford them a pleafing and ftrengthening meal. From the great degree of ftrength and nourithment which are conveyed into animal bodies by a fmall bulk of fugar, it may be given to horfes with great advantage. A pound of fugar with grafs or hay, I have been told, has fupported the ftrength and fpirits of a horfe during a whole day's labour in one of the Weft India iflands. A larger quantity given alone has fattened horfes and cattle during the war before laft in Hifpaniola, for a period of feveral months, in which the exportation of fugar and the importation of grain were prevented by the want of fhips.

3. A plentiful ufe of fugar is the beft preventative of worms. The author of nature feems to have implanted a love for fweets in all children for their growth, and to ward off the difeafe of worms, 
4. I think it probable, that the frequency of malignan fevers of all kinds has been leffened by this diet, and that its more general ufe would defend that clafs of people who are inoft fubject to malignant fevers from being fo often affected by them.

5. It has been faid, that fugar injures the teeth; but this opinion now has fo few advocates, that it does not merit a ferious refutation.

It has been a fubject of enquiry, whether the maple fugar might not be improved in its quality, and increafed in its quantity, by culture. From the influence which culture has upon foreft and other trees, it has been fuppofed, that by tranfplanting the maple fugar tree into a garden, or by deftroying fuch other trees as theiter it from the rays of the fun, much advantage might accrue. I know but of onc fas. A farmer in Northampton county, in the ftate of Pennfylvania, planted a number of thefe trees above twenty years ago in his meadow, and he declares that the quality is fo improved, that from three gallons of the fap he obtains every year a, pound of fugar; and it is a known circumftance that, to produce the fame quantity of fugar from the trees which grow wild in the wood, it requires five or fix gallons of fap. To tranfmit to future generations all the advantages which have been here enumerated, it is neceffary that this tree hould be cultivated in the old and improved parts of the United States, and a bounty given upon the maple fugar by Govcmment. Afterwards men would find out their own advantage in rearing them. An orchard confifting of 200 trees, planted upon a common form, would yield more profit than the fame number of apple or any other trees. If a greater cxpofure of a tree to the action of the fun has the fame eficet upon the maple that it has upon other trees, a larger quantity of fugar might reafonably be expected from each tree planted in an orchard. Allowing it to be only feven pounds, then 200 trees will yield 1400 pounds of fugar; and deducting 200 from the quantity for the confumption of the family, there will remain for fale 1200 pounds, 
pounds, which at 6-90 of a dollar per pound will yield an annual profit to the farmer of 80 dollars. Should this mode of tranfplanting for the purpofe of obtaining fugar be fuccefsful, it will not be a new one. The fugar cane of the Weft Indics was brought originally from the woods of the Eaft Indies by the Portuguefe, and cultivated at Madeira, from whence it was tranfplanted directly or indirectly to all the fugar iflands of the Weft Indies.

In contemplating the prefent opening profpects in human affairs, I am led to expect that a material fhare of the happinels which. Heaven feems to have prepared for all mankind, will be derived chiefly from the manufactory and general ufe of the maple fugar, which I flatter myfelf will not be confined to us, but will extend itfelf to other nations. Writh this viesv of the fubject, I cannot help contemplating a fugar American maple tree with a fpecies of affec.tion and even veneration; for I have perfuaded myfelt ts behold in it the happy means of rendering the commerce and flavery of our African brethren in the Weit India iflands as unnecellary as it has always béen inhuman and unjuft *.

XV. An Aicount of Mr. PAn N's Journey into the Intorion Parts of. Africa. From the Proccedings of the Africaus Allociation, 1798 .

$\mathrm{T}$

HE account of the proceedings of the Africin ARuciation, from which the following extract is taken, though it abounds with many curious particulars which we have been obliged to omit, contains but a fmall part of the information obtained by Mr. Park during the courfe of his peregrinations in the wild regions of Africa. A detailed relation of

* The friends to the ibolition of the Slave Trade fhould not allow the information contained in this aricle to efape their sotice. It would require very little cxpence or induftry to introduce the fugar maple into England, where it prould probably thrive as well as in America. $T$. 